\title{
Genotoxicity and Histopathological Assessment of Raw and Simulated Leachates exposed to Mice
}

\section{*11YIOLA, OA $;{ }^{2}$ ADEYEMI-ALE, OA $;{ }^{1}$ ANIFOWOSHE, AT $;{ }^{2}$ OLAFIMIHAN, TF}

\author{
${ }^{I}$ Cell Biology and Genetics Unit, Department of Zoology, University of Ilorin, P.M.B 1515, Ilorin, Nigeria \\ ${ }^{2}$ Ecology and Environmental Biology Unit, Department of Zoology, University of Ilorin, P.M.B 1515, Ilorin, Nigeria \\ ${ }^{\dagger \dagger}$ Corresponding author address: E-mail: iyiola_yinka@yahoo.com \\ Telephone: +2348038635656
}

\begin{abstract}
Indiscriminate solid waste disposal to the environment without proper treatment poses a serious threat to the public health. This study was carried out to investigate genotoxicity of the raw and simulated leachates samples collected from Amilegbe municipal dump site located in Ilorin metropolis in Nigeria. Some of the physicochemical properties of both raw and simulated leachate samples were determined. Mice were exposed to $1 \%, 2.5 \%, 5 \%, 10 \%$ and $25 \%$ (raw leachate) and 1\%,5\% and 10\% concentrations (simulated leachate) respectively for 35 days. Distilled water and colchicine were used for negative and positive control respectively. Two standard genotoxicity tests namely abnormal sperm-head morphology and micronucleus (MN) assays were used to assess possible genotoxicity of the raw and simulated leachates samples. Sperm head morphology assay showed some abnormalities (folded, amorphous, banana shaped, two tails, pin tail among others) and the frequencies of the abnormalities increases was concentrationdependent. Congestion, necrosis, degeneration and appearance of vacuolation were observed in the histopathological analysis of the liver. The histopathological changes were also more pronounced with higher concentrations of raw and simulated leachates. $\mathrm{MN}$ and abnormal nuclei frequencies also showed statistically significant differences ( $\mathrm{p}>0.05)$ such that $\mathrm{MN}$ and other nuclear abnormalities reached the maximum at the highest concentration $(25 \%>10 \%>5 \%$ $>2.5 \%>1 \%$ ). This study shows that the raw and simulated leachates contain potentially genotoxic and cytotoxic substances capable of causing DNA damage. CJASEM

https://dx.doi.org/10.4314/jasem.v21i5.11
\end{abstract}

Key words: leachates; sperm head morphology assay; histopathology; blood; micronucleus

The industrialization age has seen a lot of innovations in technology, medicine, business and other sectors of the economy. In spite of the immense benefits provided by these innovations, there are adverse impacts, one of which includes the enormous generation of waste that results from various industrial activities. This menace is even more worrisome in a highly populated country like Nigeria, as this translates to generation of more wastes compared to other less populated countries, coupled with the lack of proper waste disposal methods.

Bakare et al., (2013) reported that landfills in developing and some developed nations are unsanitary without liner, covers and leachate collecting systems. They are located in public places surrounded by residential quarters and in wetland or other places with seasonally high water tables. Sometimes wastes are disposed into water bodies and around river banks, in gullies excavated by erosions and human activities, in gutters and channels constructed for flooding and burning on major roads. These disposal methods are capable of releasing hazardous substances into the environment which can endanger the survival of living organisms including human (Alimba, 2013).

According to Bialowiec, (2011), he described landfill leachate as an intricate mixture of constituents such as dissolved organic matter, inorganic macro components, heavy metals and a wide range of xenobiotic organic compounds. Effects of leachates are weakened with distance from the source of generation but notwithstanding; it can still cause pollution of surface and groundwater, organic carbon affecting odour and taste of groundwater, nitrogen compounds producing eutrophication in surface waters and high nitrates in drinking water, and toxic heavy metals in ground and surface waters (Robinson, 1983). Some of the constituent compounds are proven mutagens, carcinogens, teratogens and are also capable of causing tissue and organ damages.

Study carried out by Bakare et al., (2005) revealed that landfill leachate is capable of inducing spermatotoxic effects. Similar reports by Alimba et al., (2006), Amahdar et al., (2009), Alabi and Bakare (2011) and Alimba et al., (2012) further reported the genotoxic and necrotic effects of leachates obtained from various dump sites. Tewari et al., (2006) reported that DNA damage can occur in bone marrow and blood cells of mice exposed to municipal sludge leachates. Histopathology profiles of the liver was also carried out in order to assess the effects of the varying concentrations of leachates samples on mice due to the significance of the liver as one of the most sensitive predictors of chemical toxicity (Tayeb et al. 2010; Alimba et al. 2012). 
In this study, abnormal sperm head morphology and micronucleus assays were used to evaluate the possible DNA damage in male Swiss albino mice upon exposure to varying concentrations of municipal sludge leachates collected from a dump site located within the city of Ilorin, Nigeria.

\section{MATE RIALS AND METHODS}

Chemicals: Sampling Collection and Storage: The sampling site is a landfill located at Amilegbe, Ilorin, Kwara State and it is located on Latitude $8^{0} 30^{\prime} \mathrm{N}$ and Longitude $4^{0} 35^{\prime} \mathrm{E}$. Raw leachate samples were collected from 20 leachate wells and a composite sample was made by mixing them thoroughly, after which it was transferred to the laboratory in prewashed plastic containers (10 L capacity), filtered to remove debris and stored at $4{ }^{\circ} \mathrm{C}$ until use. This was considered as the stock solution and designated Amilegbe raw leachate (ARL). Simulation of leachates was done using the standard method provided by the American society for testing and material (ASTM) (Perket et al., 1982; Alimba et al., 2006). The raw and simulated samples were filtered to remove debris, the $\mathrm{pH}$ was measured, and the sample stored at $4{ }^{\circ} \mathrm{C}$ until use. They were designated A raw leachate (ARL) and $\mathrm{B}$ simulated leachate (BSL) respectively. The simulated samples were also filtered to remove debris, the $\mathrm{pH}$ was measured, and the sample stored at $4^{\circ} \mathrm{C}$ until use and designated as $\mathrm{B}$ simulated leachate (BSL) respectively.

Physicochemical parameters and heavy metal analysis: The physical and chemical properties of the leachate samples were determined in accordance with standard methods (USEPA, 1996; APHA, 2005). Standard physical and chemical parameters assessed are chemical oxygen demand (COD), biochemical oxygen demand (BOD), total dissolved solids (TDS), alkalinity, chlorides, sulphates, ammonia and nitrates. The concentrations of seven heavy metals namely copper $(\mathrm{Cu})$, iron $(\mathrm{Fe})$, lead $(\mathrm{Pb})$, cadmium $(\mathrm{Cd})$, manganese $(\mathrm{Mn})$, mercury $(\mathrm{Hg})$, and arsenic (As) were assessed in each of the two leachate samples using acid digestion method. Briefly, $100 \mathrm{ml}$ of the raw and simulated leachate samples were digested by heating the sample separately with concentrated $\mathrm{HNO}_{3}$, and the volume reduced to $3-5 \mathrm{~mL}$. This volume was then made up to $10 \mathrm{~mL}$ with $0.1 \mathrm{~N}$ $\mathrm{HNO}_{3}$. Concentrations of the metals were estimated by using an Atomic Absorption Spectrophotometer.

Treatment of Test Organisms: All animal experiments were conducted in accordance with standard guidelines on use of animals for experimental toxicology study (CIOMS, 1985). Swiss albino male mice (8-10weeks of age, $20-28 \mathrm{~g}$ ) were procured from small animal unit, Department of Zoology, University of Ilorin, Nigeria and were acclimatized for 2 weeks and no mortality was recorded during this period. They were maintained in laboratory conditions of 12 hours dark and light cycle, temperature of $26 \pm 2^{\circ} \mathrm{C}$, had access to drinking water and pelleted diets (Ladokun feed Nigeriaß) $a d$ libitum. Five mice were randomly assigned to each group such that there was a total of ten groups, including positive and negative control groups. Mice treated with an aqueous solution of colchicine (2.5 $\mathrm{mg} / \mathrm{kg} \mathrm{bw}$, IP)) and distilled water were used as positive and negative controls respectively, the ten groups were administered for 5 consecutive days, 1.0 $\mathrm{ml}$ of varying concentrations of the leachates: $1 \%$, $2.5 \%, 5 \%, 10 \%$ and $25 \%$ for raw leachates and $1 \%$, $5 \%, 10 \%$ simulated leachates (leachate: diluted with distilled water, v/v) (Wyrobek et al., 1983). A fiveweek exposure (35 days) was considered after the first day of administration. All treatments were administered intraperitoneally.

\section{Determination of Micronucleus Frequency:}

The procedure of Bakare et al., (2009) was adopted with minor modifications for the micronucleus assay. Ten groups of mice (5 mice per group, 20-28 g each were exposed to varying concentrations of the test sample $1 \%, 2.5 \%, 5 \%, 10 \%$ and $25 \%$ (raw leachate) and $1 \%, 5 \%$ and $10 \%$ (simulated leachate) (v/v, effluent/distilled water) respectively. Mice in the negative control group and positive control group injected with colchicine were also sacrificed on the $35^{\text {th }}$ day. About 2-3 hr prior to sacrifice, mice in the positive control group were injected with an aqueous solution of colchicine $(2.5 \mathrm{mg} / \mathrm{kg}$ bw, IP).

Examination of slides: In each mice, 1000 erythrocytes were counted separately for both experimental and control groups. The frequencies of micronuclei and other nuclear abnormalities in erythrocytes were detected under a Binocular microscope (OLYMPUS) using a 100x oil-immersion lens. The frequencies of MN and NA were expressed per 1000 cells. The rate of micronuclei formation at hematopoiesis is always higher than that on the completion of mitotic cycle (Grisolia and Corderio, 2000).

Mouse Sperm Morphology Assay: At the end of the 5 weeks exposure period, the mouse was sacrificed by cervical dislocation and the caudal epididymis was surgically removed. Sperm suspension from the caudal epididymis of each mouse was prepared by mincing it in normal saline, and then stained with $1 \%$ Eosin Y 9:1 (normal saline: eosin) for 45 minutes. Slides were prepared from the smears, dried and 
coded for subsequent microscopic examination. For each mouse, 800 sperm cells were assessed for morphological abnormalities according to standard procedures (Wyrobeck et.al, 1983). Sperm without tails or heads that was in contact or overlaid by other sperm or debris was excluded. Three slides per mouse was prepared and observed.

Scoring of micronuclei: Scoring of micronuclei in the interphase is technically much easier and more rapid than the scoring of chromosomal aberrations during metaphase. The micronucleus (MN) test in mice has potential for detecting clastogenic substances in aqueous media. The nuclear abnormalities observed were classified into five categories, adapting the classification proposed by Ayllon and GarciaVazquez (2000).

Histopathological analysis: Slices of the right lobe of the liver from exposed and control animals were fixed in $10 \%$ neutral buffered formalin. After 48 hours of fixation, organs were dehydrated by passing through ascending order of ethyl alcohol-water concentrations, cleared in xylene and sequentially embedded in paraffin wax blocks using rotary microtome. Tissue sections of $3-5 \mu \mathrm{m}$ thick were cut, stained with Haematoxylin-eosin (H-E), then mounted in neutral DPX medium for morphological evaluation before microscopic examination at $\mathrm{x} 400$.

Statistical Analysis: The Statistical Package for the Social Sciences (SPSS) version 16.0 and Microsoft Excel, 2010 were applied for data analysis. Data obtained were expressed as percentage frequency and mean \pm standard error. Significance at different concentration-level was tested using one-way ANOVA test and Duncan's New Multiple Range Test (DMRT) at the 0.05 probability level.

\section{RESULTS AND DISCUSSION}

Landfill leachate is a complex cocktail of constituents including dissolved organic matter, inorganic macro components, heavy metals and a wide range of xenobiotic organic compounds (Bialowiec, 2011). Although the toxic effects of leachates are weakened with distance from the source of generation, it can still be hazardous to man and other living system. Several leachates including domestic and industrial leachates constitute major sources of toxic substances to our environment. It can induce liver dysfunction (Meyer, 1983) and DNA damage (Alabi and Esan, 2014). In this present study, we investigated the genotoxic potential and histopathogical effects of raw and simulated leachates in mice. In testing for genotoxic effect, a combination of abnormal sperm- head morphology and micronucleus (MN) assays were used.

The physicochemical properties and heavy metal characteristics of the leachates (Raw and Simulated) were also determined and are shown in Table 1. The result of the physicochemical parameters and heavy metals is an indication for the observable sperm abnormalities and $\mathrm{MN}$ inductions in the exposed mice. The $\mathrm{pH}$ of both leachate samples were alkaline, although values were within USEPA and FEPA acceptable limits (8.5 and 7.9) respectively. The amount of ammonia concentration in BSL is higher than those of the borehole water $(0.8 \mathrm{mg} / \mathrm{L})$ which is an evidence of contamination of the leachates samples. The concentrations of heavy metals analyzed were far higher in the leachate samples than USEPA and FEPA limits. Results of the $\mathrm{pH}$ values from the two leachate samples showed that they fall within USEPA and FEPA acceptable limits. Values recorded for heavy metals such as $\mathrm{Cd}, \mathrm{Hg}, \mathrm{Pb}, \mathrm{Ar}$, $\mathrm{Cu}, \mathrm{Fe}$ and $\mathrm{Mn}$ were far higher in the leachate samples than borehole water, USEPA and FEPA limits. The implication of the presence of heavy metals observed in these leachates is that the samples contain toxic and possible carcinogenic and mutagenic substances which are capable of inducing genetic alterations and genome instability in the animals. In a recently documented study, cadmium chloride was reported to induce DNA damage and apoptosis of human liver carcinoma cells via oxidative stress(Skipper et al., 2016). Previous studies carried out in mouse liver by Habeebu et al. (1998) and in murine splenocytes exposed to cadmium reported by Pathak and Khandelwal, (2006) also showed that cadmium can potentially induce oxidative stress and programmed cell death (apoptosis). Presence of heavy metals in the leachate samples beyond permissible limits may cause these metals to bio accumulate in the liver, kidney and other organs which may result in cellular or DNA damage or at times induce programmed cell death known as apoptosis. Even if the concentrations of heavy metals are below FEPA specifications, biomagnifications due to gradual accumulation of heavy metals in the environment may also exert genotoxic or cytotoxic effects on living organisms present in that environment (Agboola and Fawole, 2014).

Analysis of the frequencies, mean and standard error of the micronuclei and other nuclear abnormalities observed in mice treated with various concentration of raw leachate samples were presented in Table 2. The results show that mice treated with raw leachates have increased levels of micronucleus induction in a concentration-dependent manner such that the total 
micronucleus and other nuclear abnormalities observed were in the order negative control $<1 \%<2.5 \%<5 \%<10 \%<25 \%<$ positive control. The frequency of nuclear aberrations observed in ARL and BSL groups are presented in figure 1 and 2 respectively.

The results in Table 2 showed that from 5\% concentration of leachates samples, there was concentration-dependent and linear correlation between micronucleus induction and leachate concentration. This result indicates that the ARL and BSL may contain free radicals and components that caused DNA damage in the tissues and organs of the treated mice at various concentrations. It may sound plausible to suggest that variations in the level of micronucleus induction from observed from 5\% concentration is an indication of the presence of DNA damage agents in the leachates samples which may have probably disrupted cell cycle, proper DNA replication and cellular integrity as shown in the micronucleus results.

High concentration of heavy metals observed in Table 1 might also explain the reasons for the increase in micronucleus induction observed in Table 2. Data from this study is consistent with previous report done in mice by Bakare, et al., (2003) which reported that landfill leachate has the capacity to induce toxicity and abnormal sperm head morphology (Bakare, et al., (2005). Similar study carried out by Bakare, et al., (2004) using Allium cepa assay also corroborated this suggestion that leachates from domestic solid waste are mutagenic and cytotoxic.

In table 3, the frequency of micronucleus induction was statistically significant $(\mathrm{p}<0.05)$ and concentration-dependent at all concentrations. In the treated animals, the frequency of abnormal sperm cells was statistically significant $(\mathrm{p}<0.05)$ and concentration-dependent at all concentrations. Generally, folded sperm cells were more frequent than the remaining types of aberration in all experimental groups (Figures 4 and 5). Increase in induction of micronuclei and other nuclear abnormalities in mice treated with various concentration of simulated leachate in a dosedependent manner also corroborates the suggestion that leachate samples contain potentially genotoxic substances which may be responsible for these observations. Evidences from physicochemical analysis in Table 1 and histopathology results shown in Figure 6-15 also could also be adduced for the reasons why there was dose-dependent increase in micronucleus induction. This is an indication of possible DNA damage and this data is in accordance with the findings of Alabi and Esan (2014) in a study done on simulated leachate of soil from petroleum, diesel and kerosene dispensing sites. Similar report by Iwegbue et al., (2007) also suggested that simulated leachate is possibly genotoxic. Micronucleus assay has been extensively used to assess genetic damage during cell division. Although the mechanism of the damage is not known but it is believed that induction of micronucleus is a true reflection of damage to the DNA (Bücker, et al., 2012). Comparison between the level of induction of cellular damage and micronucleus as shown in Table 4 is another evidence to show that simulated leachates contains more genotoxic substances than raw leachate samples. Presence of heavy metals beyond permissible limit may be responsible for these observations.

Results of evaluation of induction of abnormal sperm morphology as shown in Figure 3 are another piece of evidence that both raw and simulated leachates contain genotoxic materials. One possible explanation for the various kinds of sperm head abnormalities observed in this study is that the toxic materials present in the leachates may have interfered with the process of spermatogenesis which may have resulted in error during DNA packaging in the nucleus of the sperm head thereby giving it abnormal shape. Although it is normal that the DNA repair mechanism available during meiotic recombination should have repaired the error but it is possible that the genotoxic materials present in the leachates may have overwhelming effects on the error-free DNA double strand break repair system available only in meiosis.

Leachate samples have been previously reported to induce abnormal sperm head morphology (Bakare et al., 2005). This observation corroborates the evidence from the study carried out by Alimba, et al., 2006 who also reported a dose-dependent induction of abnormal chromosome abnormalities in rat bone marrow cells upon exposure to municipal leachates. 
Table1: Physicochemical and Heavy Metal Characteristics of the 10\% Raw and Simulated leachates.

\begin{tabular}{l}
\hline Parameters* \\
pH value \\
Alkalinity \\
Chloride ion \\
Sulphate ion \\
Ammonia \\
COD \\
BOD \\
Dissolved oxygen \\
Total dissolved solid \\
Total suspended solid \\
Total solid \\
Turbidity \\
Electrical conductivity \\
Total hardness \\
Calcium ion \\
Magnesium ion \\
Nitrate ion \\
Cadmium \\
Mercury \\
Lead \\
Arsenic \\
Copper \\
Iron \\
Manganese \\
\hline
\end{tabular}

BORE HOLE WATER

ARL

13.5

10.8

38.6

0.80

3.72

9.20

32.80

22.10

20.70

42.80

2.58

97 (us)

58.60

27.20

31.40

2.80

2.80
1.02

0.42

1.68
1.06

1.06
0.26

3.82

2.06

\begin{tabular}{ccc} 
BSL & USEPA & FEPA \\
7.90 & $6.5-8.5$ & $6.0-9.0$ \\
48.2 & - & - \\
19.8 & - & - \\
55.5 & - & 20.00 \\
8.70 & - & 0.01 \\
7.96 & - & - \\
20.4 & - & 50.00 \\
50.60 & - & - \\
41.50 & - & - \\
46.30 & - & - \\
87.80 & - & - \\
9.50 & - & - \\
1976 & - & - \\
72.80 & $0-75$ & - \\
31.40 & - & - \\
41.40 & - & - \\
6.30 & 10.0 & - \\
7.86 & 0.05 & 0.05 \\
1.26 & & \\
9.61 & 0.02 & 0.01 \\
7.82 & 0.01 & - \\
7.66 & 1.30 & - \\
12.06 & 0.30 & 0.05 \\
5.59 & 0.05 & 0.05 \\
\hline
\end{tabular}

*All values are in $\mathrm{mg} / \mathrm{L}$ except $\mathrm{pH}$ and salinity (parts per thousand); FEPA: Federal Environmental Protection Agency; USEPA: United States Environmental Protection Agency; COD: Chemical oxygen demand; BOD: Biochemical oxygen demand.

Table 2: Analysis of the frequencies, mean and standard error of the Micronuclei and other nuclear abnormalities observed in Swiss albino mice treated with various concentration of raw leachate.

\begin{tabular}{lccccccc}
\hline Concentrations & Total & Micronucleus & Binucleated & Lobed & Notched & Blebbed & Others \\
Negative Control & 14 & $0.5 \pm 0.5$ & $19.0 \pm 1.0$ & $2.0 \pm 5.0$ & $9.0 \pm 2.0$ & $4.5 \pm 0.5$ & $5.0 \pm 1.0$ \\
$1.0 \%$ & 232 & $13.5 \pm 3.5$ & $25.5 \pm 4.5$ & $5.0 \pm 2.0$ & $10.0 \pm 1.0$ & $18.5 \pm 3.5$ & $6.0 \pm 1.0$ \\
$2.5 \%$ & 244 & $15.5 \pm 0.5$ & $11.5 \pm 3.5$ & $15.5 \pm 1.5^{*}$ & $12.5 \pm 2.5$ & $20.0 \pm 0.0$ & $17.5 \pm 1.0$ \\
$5.0 \%$ & 270 & $23.5 \pm 1.5$ & $15.0 \pm 0.0$ & $23.0 \pm 1.0^{*}$ & $30.0 \pm 0.0^{*}$ & $32.5 \pm 2.5^{*}$ & $10.0 \pm 0.0$ \\
$10.0 \%$ & 368 & $30.5 \pm 4.5^{*}$ & $43.0 \pm 5.0^{*}$ & $36.5 \pm 1.5^{*}$ & $45.5 \pm 0.5^{*}$ & $40.5 \pm 0.5^{*}$ & $19.0 \pm 1.0^{*}$ \\
$5.0 \%$ & 377 & $42.5 \pm 2.5^{*}$ & $40.0 \pm 5.0$ & $37.5 \pm 1.5^{*}$ & $33.5 \pm 3.5^{*}$ & $44.0 \pm 4.0^{*}$ & $37.5 \pm 7.5^{*}$ \\
Positive Control & 401 & $40.0 \pm 5.0^{*}$ & $41.5 \pm 10.5$ & $36.5 \pm 6.5$ & $36.5 \pm 6.5^{*}$ & $18.5 \pm 1.5$ & $21.5 \pm 0.5^{*}$ \\
\hline
\end{tabular}

*Statistically different from negative control $(\mathrm{p}<0.05)$, No of animals/group=3; Total no. of nuclei scored/concentration=1000

Several reasons can also be adduced to explain the elevated and statistically significant increase in the frequency $(\%)$ of sperm head abnormalities in the exposed mice treated with leachate samples at 5,10 , $25 \%$ concentrations and positive control (raw leachate) and 1,5, 10\% and positive control (simulated leachate) in Table 5 and 6.It is possible that both the raw and simulated leachate samples may contain genotoxic and or cytotoxic materials which may have possibly led to error in DNA packaging during cell cycle as evidenced in the sperm shape abnormalities. Another reason is that the leachates sample may have induced apoptosis being highly toxic to the spermatozoon disrupting the normal differentiating process during spermatogenesis due to presence of heavy metals observed in Table 1. Thus, genotoxicity of municipal leachate samples has been extensively studied and there are plenty of overwhelming evidences from these previous studies to support the suggestion that municipal leachate samples is potentially genotoxic (Alimba et al., 2006; Bakare and Adeyemo, 2004; Bakare et al. 2005; Bakare et al. 2007; Sang and Li 2004; Sang and Li 2005; Siddique et al. 2005; Tewari et al. 2005).

Analysis of histological parameters has proven to be a reliable biomarker and may help indicate the health status of the experimental animal being studied. Therefore in the present study, histopathological analysis of the liver tissues in the negative control group showed a normal cellular architecture of the liver tissues (Figure 6). It was observed that the treated groups (both raw and simulated leachates) at different exposure periods showed several pathological changes throughout the experimental period due to disruption of the normal cellular architecture of the liver (Figure 6-15).These are indications of different types of cellular damages to the liver of the treated groups which may have been caused by raw and simulated leachate samples. The 
various histopathological changes observed markedly in the liver as shown in this study could be due to the role of this organ as a key player involved in detoxification of toxic substances in the vertebrates' body. It is not surprising therefore that there were conspicuous histopathological damages in the liver of mice in treated group. Also, liver has the capacity to bioaccumulate toxicants and so damage to the liver may help predict chemical toxicity in all vertebrates.

Table 3: Analysis of the frequencies, mean and standard error of the Micronuclei and other Nuclear abnormalities observed in Swiss albino mice treated with various concentration of simulated leachate.

\begin{tabular}{lccccccc}
\hline Concentrations & Total & MN & Binucleated & Lobed & Notched & Blebbed & Others \\
Negative Control & 14 & $0.5 \pm 0.5$ & $19.0 \pm 1.0$ & $20.0 \pm 5.0$ & $19.0 \pm 2.0$ & $14.5 \pm 0.5$ & $5.0 \pm 1.0$ \\
$1 \%$ & 370 & $36.5 \pm 7.5^{*}$ & $35.5 \pm 7.5$ & $30.0 \pm 15.5$ & $32.0 \pm 10.0$ & $50.5 \pm 9.5$ & $20.0 \pm 10.0$ \\
$5 \%$ & 482 & $44.0 \pm 6.0^{*}$ & $46.5 \pm 0.5$ & $37.5 \pm 7.5$ & $47.5 \pm 12.5$ & $50.5 \pm 9.5$ & $22.5 \pm 7.5$ \\
$10 \%$ & 814 & $40.0 \pm 5.0^{*}$ & $82.5 \pm 11.5^{*}$ & $67.5 \pm 8.5^{*}$ & $64.0 \pm 9.0^{*}$ & $49.0 \pm 13.0^{*}$ & $64.0 \pm 3.0$ \\
Positive Control & 401 & $80.0 \pm 10.0^{*}$ & $41.5 \pm 10.5$ & $36.5 \pm 6.5$ & $42.5 \pm 7.5$ & $18.5 \pm 1.5$ & $21.5 \pm 0.5$ \\
\hline
\end{tabular}

*Statistically different from negative control $(\mathrm{p}<0.05)$, No of animals/group $=3$, Total no. of nuclei scored/concentration $=1000$

Table 4: Frequencies of Micronucleus and other nuclear abnormalities found in ARL and BSL test and control groups.

\begin{tabular}{|c|c|c|c|c|c|c|c|c|c|}
\hline $\begin{array}{l}\text { Concentrations } \\
\text { of test samples }\end{array}$ & $\begin{array}{l}\text { Raw } \\
\text { Leachate } \\
\text { MN }\end{array}$ & $\mathrm{BN}$ & LOBED & NOTCHED & BLEBBED & OTHERS & TOTAL & MEAN & SD \\
\hline Negative & 1 & 3 & 2 & 3 & 2 & 3 & 14 & 2.33 & 0.82 \\
\hline Control & & & & & & & & & \\
\hline $1 \%$ & 47 & 51 & 77 & 20 & 37 & 12 & 244 & 40.67 & 23.36 \\
\hline $5 \%$ & 47 & 23 & 31 & 25 & 71 & 35 & 232 & 38.67 & 17.99 \\
\hline $2.5 \%$ & 47 & 30 & 48 & 60 & 65 & 20 & 270 & 45.00 & 17.25 \\
\hline $10 \%$ & 61 & 86 & 63 & 91 & 29 & 38 & 368 & 61.33 & 24.82 \\
\hline $25 \%$ & 85 & 80 & 65 & 67 & 40 & 40 & 377 & 62.83 & 19.24 \\
\hline Positive & 80 & 83 & 73 & 85 & 43 & 43 & 401 & 66.83 & 21.27 \\
\hline
\end{tabular}

\begin{tabular}{|c|c|c|c|c|c|c|c|c|c|}
\hline \multirow[b]{2}{*}{ Negative } & \multicolumn{9}{|c|}{$\begin{array}{l}\text { Simulated } \\
\text { Leachate }\end{array}$} \\
\hline & 1 & 3 & 2 & 3 & 2 & 3 & 14 & 2.33 & 0.82 \\
\hline Control & 47 & 51 & 77 & 20 & 37 & 12 & 244 & 40.67 & 23.36 \\
\hline $1 \%$ & 47 & 23 & 31 & 25 & 71 & 35 & 232 & 38.67 & 17.99 \\
\hline $5 \%$ & 47 & 30 & 48 & 60 & 65 & 20 & 270 & 45.00 & 17.25 \\
\hline $10 \%$ & 61 & 86 & 63 & 91 & 29 & 38 & 368 & 61.33 & 24.82 \\
\hline Positive & 85 & 80 & 65 & 67 & 40 & 40 & 377 & 62.83 & 19.24 \\
\hline Control & 80 & 83 & 73 & 85 & 37 & 43 & 401 & 66.83 & 21.27 \\
\hline
\end{tabular}

*MN- Micronucleus; /*BN- Binucleated'*SD- Standard Deviation

The histopathological analysis of the liver of the mice exposed to raw and simulated leachates was carried out. Hepatic sections of negative control mice showed a normal architecture of the hepatocytes. The lesions observed in exposed rats ranged from mild to severe congestion of the central vein and necrotizing hepatitis, which was shown by degeneration of hepatocytes. In this study, it was observed that the concentrations of lead in raw and simulated leachates are two and nine times higher respectively than the permissible standard according to FEPA specifications.

Abnormal sperm head morphology assay was carried out to investigate error that may result from DNA packaging during cell division and the types of shapes observed are shown in Figures 3. In the present study, the sperm head morphology of mice in negative control group (treated with distilled water) showed normal shape and those of the other treated groups (Figures 3) showed various kinds of sperm abnormalities such as amorphous, short tail, multiple tails, folded sperm, hook at wrong angle, kink tail, knobbed hook and others. Result of statistical analysis (ANOVA) of the mean values of occurrence of sperm head abnormality induced by raw and simulated leachate samples in the treated group and controls are presented in Table 5 and 6 respectively. These showed, compare to negative control(distilled water), that there were statistically significant ( $p>$ 0.05) differences in induction of sperm head abnormality in test groups treated with 5, 10, 25\% leachate samples including positive control for raw leachate samples and in test groups treated with 1, 5, 
$10 \%$ simulated leachate samples and positive control. Major types of sperm-shape abnormality observed were those with knobbed hook, amorphous and folded sperms.

Table 5: Summary of Abnormal sperm morphology induced in Swiss albino mice at different concentrations of Raw Leachates

\begin{tabular}{cccc}
\hline Concentrations & $\begin{array}{c}\text { Total no of } \\
\text { abnormalities }\end{array}$ & $\begin{array}{c}\% \\
\text { Abnormalities }\end{array}$ & $\begin{array}{c}\text { Mean } \\
\text { aberration } \\
\pm \text { S.E }\end{array}$ \\
$\begin{array}{c}\text { Negative } \\
\text { Control }\end{array}$ & 50 & 2.08 & $16.67 \pm 0.88$ \\
$1 \%$ & 58 & 2.41 & $19.30 \pm 4.09$ \\
$2.5 \%$ & 77 & 3.21 & $25.67 \pm 2.67$ \\
$5 \%$ & 113 & $4.71^{*}$ & $37.67 \pm 2.18$ \\
$10 \%$ & 118 & $4.92^{*}$ & $39.33 \pm 1.20$ \\
$25 \%$ & 119 & $4.96^{*}$ & $39.67 \pm 2.67$ \\
Positive & 151 & $6.29^{*}$ & $50.33 \pm 5.78$ \\
Control & & &
\end{tabular}

*Statistically different from negative control $(\mathrm{p}<0.05) ;$ No. of animal/group $=3$; Total no. of sperm cells scored/concentration $=1000$

Table 6: Summary of Abnormal Sperm morphology induced in Swiss albino mice at different concentrations of Simulated Leachates.

\begin{tabular}{cccc}
\hline Concentrations & $\begin{array}{c}\text { Total } \\
\text { abnormalities }\end{array}$ & $\begin{array}{c}\text { Percentage } \\
\text { abnomalities }\end{array}$ & $\begin{array}{c}\text { Mean } \\
\text { aberration } \\
\pm \text { S.E }\end{array}$ \\
\hline Negative control & 50 & 2.08 & $16.67 \pm 0.88$ \\
$1 \%$ & 131 & $5.45^{*}$ & $43.67 \pm 3.48$ \\
$5 \%$ & 159 & $6.60^{*}$ & $53.00 \pm 4.63$ \\
$10 \%$ & 182 & $7.58^{*}$ & $60.67 \pm 4.63$ \\
Positive control & 151 & $6.29^{*}$ & $50.33 \pm 5.78$ \\
\hline
\end{tabular}

*Statistically different from negative control $(\mathrm{p}<0.05)$; No. of animal/group $=3$, Total no. of sperm cells scored/concentration $=1000$

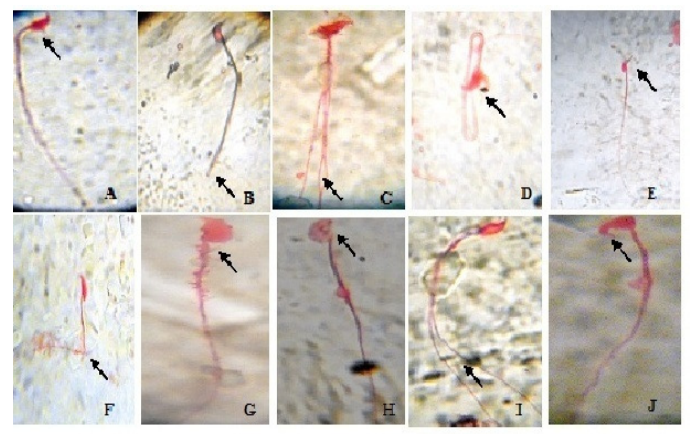

Fig 3: Various kinds of abnormal sperm cells induced in mice exposed to different concentrations of raw and simulated leachates (A) normal sperm cell, (B) short tail (C) three tails (D) folded sperm, (E) hook at wrong angle, (F) kink tail (G) No hook $(\mathrm{H})$ amorphous head (I) Two tails (J) Knobbed hook. All Figures are presented at $\mathrm{x} 1000$ magnification.

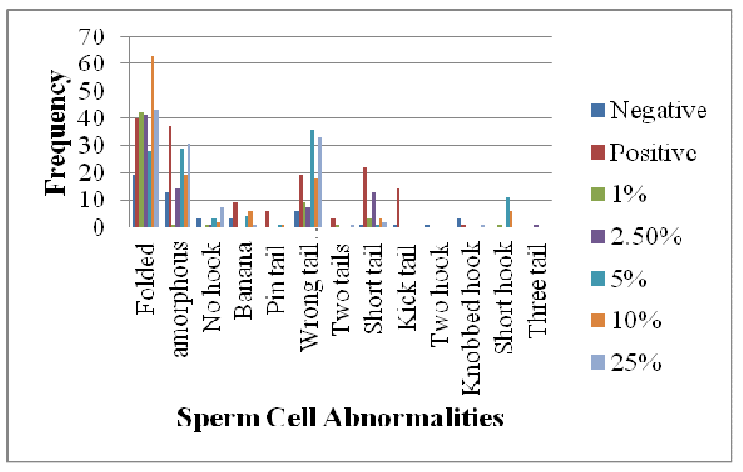

Fig 4: Frequencies of each type of sperm aberrations induced at different concentrations of raw leachates.

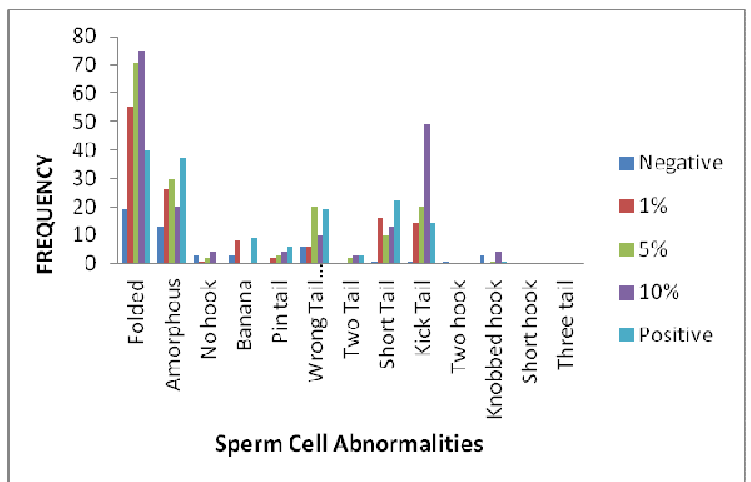

Fig 5: Frequencies of each type of sperm cell abnormalities induced by different concentrations of simulated leachates

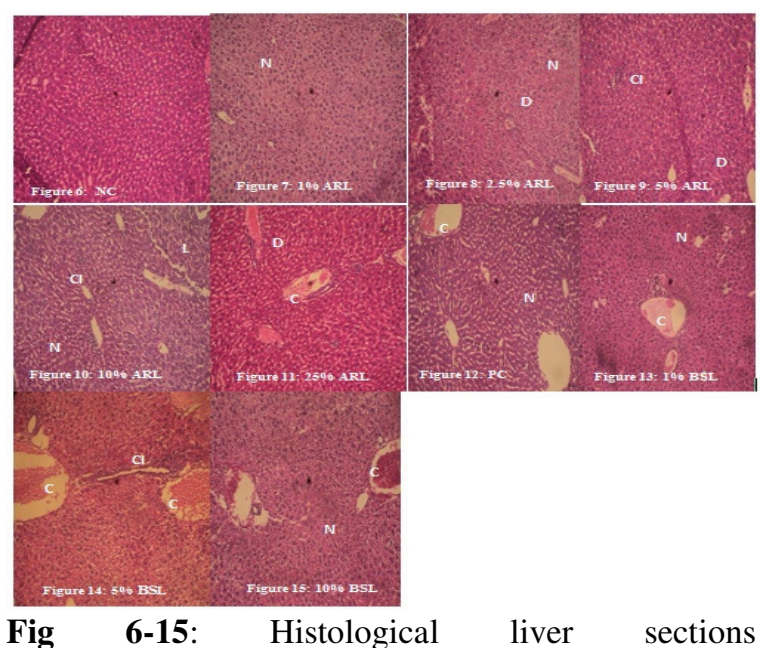

(Magnification $\times 1000$ ); $\mathrm{NC}=$ Negative control; $\mathrm{PC}=$ Positive control; $\mathrm{ARL}=$ 'A' Raw Leachate; $\mathrm{BSL}=$ 'B' Simulated Leachate; $\mathrm{CI}=$ Cellular infiltrations; $\mathrm{C}=$ Congestion of the central vein; $\mathrm{V}=$ Vacuolation; $\mathrm{N}=$ Necrosis and $\mathrm{D}=$ Disruption of hepatic cords. 
Acknowledgement: We wish to thank the authority of the Department of Zoology, University of Ilorin, Ilorin, Nigeria for making available the facilities used for this study.

\section{REFERENCES}

Agboola, OA; Fawole, OO. (2014). Chronic Toxicity of Pharmaceutical Effluent to Clarias gariepinus (Burchell, 1822). Covenant Journal of Physical and Life Sciences 1(2):27-42.

Alabi, OA; Bakare, AA. (2011). Genotoxicity and mutagenicity of electronic waste leachates using animal bioassays. Toxicol. Environ. Chem., 10.1080/02772248.2011.561949

Alabi, AO; Esan, EB. (2014). Simulated Leachate of Soil from Petroleum, Diesel and Kerosene Dispensing Sites Induced DNA Damage using Ames Salmonella Test and SOS Chromo Test. JSM Biotechnol Bioeng 2(2): 1044.

Alimba, CG; Bakare, AA; Latunji, CA. (2006). Municipal landfill leachates induced chromosome aberration in rat bone marrow cells. Afri. J. Biotech. 5(22):2053-2057.

Alimba, CG; Bakare, AA; Aina, OO. (2012). Liver and kidney dysfunction in wistar ratsexposed to municipal landfill leachate. Resources Environ. 2(4):150-163.

Alimba, CG. (2013). DNA and systemic damage induced by landfill leachates and health impacts of human exposure to landfills in Lagos and Ibadan, Nigeria. Ph.D thesis, Department of Zoology, University of Ibadan, Nigeria. 258pp.

Amahdar, L; Anouar, A; Ababou, B; Verschaeve, L; Hilali, A. (2009). In vitro genotoxicity of Settat town landfill leachate, Morocco. ArhHigRadaTokiskologi, 60:179-184.

American Public Health Association (APHA), Standard Methods for the Examination of Water and Wastewater, American Public Health Association (APHA), Washington, DC, USA, 20th edition.

Ayllon, F; Garcia-Vazquez, E. (2000). Induction of micronuclei and other nuclear abnormalities in European minnow Phoxinus phoxinus and mollie Poecilia latipinna: An assessment of the fish micronucleus test. Mutat Res. 467:177-186.
Jenmi, HB.(2009). Genotoxicity assessment of a pharmaceutical effluent using four bioassays. Genetics and Molecular Biology, 32 (2): 373381.

Bakare, AA; Lateef, A, Amuda, OS; Afolabi, RO. (2003). The aquatic toxicity and characterization of chemical and microbiological constituents of water samples from Oba River, Odo-Oba, Nigeria. Asian J. Microbiol. Biotechnol. Environ. Sci., 5: 11-17.

Bakare, AA; Wale-Adeyemo, AR. (2004). The mutagenic and cytotoxic effects of leachates from domestic solid wastes and Aba-Eku landfill, Nigeria on Allium cepa. Nature Environ. Pollut. Tech. 3 (4), 455-462.

Bakare, AA; Mosuro, AA; Osibanjo, O. (2005). An in vivo evaluation of induction of abnormal sperm morphology in mice by landfill leachates. Mutat. Res. 582:23-34.

Bakare, AA; Oshodi, KA; Adelodun, AT. (2007). Paracetamol and caffeine induced sperm shape abnormalities in mice. Africa Journal of Animal and Biomedical science. 2:11-16

Bakare, AA; Alimba, CG; Alabi, OA. (2013).Genotoxicity and mutagenicity of solid waste leachates: A review. African Journal of Biotechnology.12(27): 4206-4220.

Bücker, AM; Carvalho, S; Conceição, M.B; AlvesGomes, J.A. (2012). Micronucleus test and comet assay in erythrocytes of the Amazonian electric fish Apteronotus bonapartii exposed to benzene J. Braz. Soc. Ecotoxicol. 7 (1): 65-73.

Białowiec, A. (2011). Hazardous Emissions from Municipal Solid Waste Landfills.Contemporary Problems of Management and Environmental Protection.No. 9.

CIOMS (1985). International Guiding Principles for Biomedical Research Involving Animals. Altern Lab Anim. PMID: 11653736

Grisolia, CK; Cordeiro, CMT. (2000). Variability in micronucleus induction with different mutagens applied to several species of fish. Genet Mol Biol. ;23:235-239.

Habeebu, SS; Liu, J; Klaassen, CD. (1998). Cadmium-induced apoptosis in mouse liver.Toxicol. Appl. Pharmacol.149, 203-209

Bakare, AA., Okunola, AA. Adetunji, OA and 
Iwegbue, CMA; Arimoro, FO; Nwajei, GE. (2007). The genetoxicity screening of simulated leachate from semi-urban waste dumps in the Niger Delta, Nigeria analysed by Allium test. Research Journal of Environmental Sciences, 1: 310-316.

Palhares, D; Grisolia, CK. (2002). Comparison between the micronucleus frequencies of kidney and gill erythrocytes in tilapia fish, following mitomicin C treatment. Genet. Mol. Biol, 25(3): 281-284.

Pathak, N; Khandelwal, S. (2006). Oxidative stress and apoptotic changes in murine splenocytes exposed to cadmium. Toxicology 220: 26-36.

Perket, CL; Krueger, JR; Whitehurst, DA. (1983). The use of extraction tests for deciding waste disposal options. Trends. Anal. Chem., 1: 342347.

Robinson, HD. (1983). Problems of leachate from domestic waste tips in analysis for environmental protection. Anal. Proc. 20.

Sang, N; Li, G. (2004). Genotoxicity of municipal landfill leachate on root tips of Viciafaba. Mut.Res. 560: 159-165.

Sang, N; Li, G. (2005). Chromosomal aberrations induced in mouse bone marrow cells by municipal landfill leachate. Environ. Toxicol.Pharmacol .20: 219-224.

Siddique, HR; Gupta, SC; Dhawan, A; Murthy, RC; Saxena, DK; Chowdhuri, DK. (2005). Genotoxicity of Industrial Solid Waste Leachates in Drosophila melanogaster. Environ. Mol. Mutagen 46:189-197.

Skipper, A; Sims, JN; Yedjou, CG; Paul, B; Tchounwou, PB. (2016).Cadmium Chloride Induces DNA Damage and Apoptosis of Human Liver Carcinoma Cells viaOxidative Stress. Int. J. Environ. Res. Public Health 13 (1):88-97.

Tayeb, W; Nakbi, A; Trabelsi, M; Attia, N; Miled, A; Hammami, M. (2010). Hepatotoxicity induced by sub-acute exposure of rats to 2,4Dichlorophenoxyacetic acid based herbicide "DesormoneLourd". J Haz Mat.; 180: 225-233.

Tewari, A; Chauhan, LKS; Kumar, D; Gupta, SK. (2005). Municipal sludge leachate-induced genotoxicity in mice-a subacute study. Mutat. Res. 587: 9-15.

Tewari, A; Dhawan, A; Gupta, SK. (2006). DNA damage in bone marrow and blood cells of mice exposed to municipal sludge leachates. Environ. Mol. Mutagen. 47:1-6.

United States Environmental Protection Agency. (1996). Acid digestion of sediments sludge and soils. Method-3050B, USEPA, Washington, DC.

Wyrobek, AJ; Gordon, LA; Burkhart, JG; Francis, MW; Kapp, RW; Jr, Letz, G; Malling, HG; Topham, JC; Whorton, MD. (1983). An evaluation of the mouse sperm morphology test and other sperm tests in non-human mammals. A report of the United States Environmental Protection Agency Gene -Tox Programme. Mutat Res., 115:1-72. 